\title{
Export Potential of Sri Lanka and the Determinants of Exports: A Gravity Model Approach
}

\author{
Vipula Wickramarachchi ${ }^{1}$ \\ Australian National University, Australia \\ Central bank of Sri Lanka
}

\begin{abstract}
This research attempts to investigate the determinants of exports of Sri Lanka and to estimate the potential exports for the period 2000-2013, using a gravity model augmented with stochastic frontier approach. It uses panel data for 56 major export destinations of Sri Lanka. Results show that importing country's GDP and colonial relationship have positive impact on Sri Lanka's exports. In addition, the difference between the factor endowments of Sri Lanka and importing country has a positive impact. However, the distance and trade resistance of the importing country have negative impact on Sri Lanka's exports. Further, Sri Lanka's actual exports have achieved only 15 per cent of its potential during the period 2000 to 2013. There is considerable differences in region-wise performance which shows that Sri Lanka has done considerably well in the traditional markets such as the US and EU but has fallen well short of its potential in the other regions.
\end{abstract}

Keywords: Export Potential, Gravity Model, Stochastic Frontier Analysis

\section{Introduction}

Even though the recent history of Sri Lanka is plagued with civil war, political instability and natural disasters, its economy has shown remarkable resilience. Since the introduction of open economic reforms and the establishment of Export Promotion Zones in late 1970s, exports grew steadily and helped to generate employment and reduce poverty levels. Since the end of the civil war in 2009, economic growth has accelerated and export sector has kept pace with changes in economy. Having recorded 7.2 per cent and 7.4 per cent growth rate in 2013 and 2014 respectively, the Sri Lankan economy is forecasted to grow at 7.0 per cent and 7.3 per cent, respectively in 2015 and 2016. Inflation fell markedly and current account deficit narrowed further. Exports expanded by $7.0 \%$ in 2014 and amounted to $\$ 11.1$ billion, following growth recovery in the second half of 2013. However, export performance showed some weakness toward the end of 2014, when exports were down by $13.7 \%$ year on year in October and $10.7 \%$ in November. (Asian Development Outlook 2015)

India has been the major trading partner of Sri Lanka followed by China and the USA for a considerable period of time. Industrialised countries, the USA and the UK in particular, remained the largest export destinations, while Asia particularly India and China remained the major import origins. In the export front, the USA has been the main destination for Sri Lanka's exports for a long period since 1979. In 2014, share of exports to USA out of total exports recorded 24.5 per cent. The UK was the second largest export destination as of 2014 with an export share of 10 per cent, followed by India, Italy and Germany, respectively. Composition of exports has also changed overtime with shift of prominence from export Agricultural products such as Tea, Rubber and Coconut in the colonial and post independence era to industrial goods such as garments (Central Bank of Sri Lanka 2014).

Sri Lanka is involved in two bilateral free trade agreements with India and Pakistan. Negotiations have already been initiated for a third such agreement with China. In addition, Sri Lanka is also a member of WTO and other regional trade agreements such as South Asian Free Trade Area (SAFTA), Asia Pacific Trade Agreement (APTA) and has consented for BIMSTEC. Further, Sri Lanka also benefited from GSP+ concessional access to the European Union, which was scrapped in 2010 ago due to unfavorable human rights record of the Sri Lankan Government. In January 2015, EU restricted imports of fish products from Sri Lanka due to the use of illegal fishing gear and discussions are underway to regain access.

Government support for exports has been improving overtime. Institutional support for exports is amply available through organizations such as Export Development Board, Board of Investment and Sri Lanka Export Credit Insurance Corporation. In addition, Post-war economic optimism in has drawn lot of enthusiasm among policy makers to improve the export performance of the country.

${ }^{89}$ I wish to extend my heart-felt thanks to Prof. Kaliappa Kalirajan of the Australian National University for the academic supervision, guidance and the generously in sharing his knowledge, experience and ideas. The views expressed in this study are those of the author and do not necessarily indicate the views of the Central Bank of Sri Lanka. 
In this backdrop, Government has embarked on National Export Strategy 2015-2020 to further increase the volume of exports with an ambitious target of USD 20Bn by 2020 which means doubling of current export turnover. This requires an annual average growth rate of 14.5 per cent (Kalegama 2015).

However, export performance of Sri Lanka has not been satisfactory in the recent past. Ratio of exports to GDP has been falling since 2000. Export share of Sri Lanka in the world is declining while the Sri Lanka's share of exports from all developing countries is also falling. When it comes to the recent export performance, Sri Lanka has been clearly falling behind its peers such as Bangladesh and Vietnam. These suggest that Sri Lanka's problems in export sector is home grown rather than due to issues in the global markets (Kalegama 2015). Further, with the increase in per capita income level, it is inevitable that Sri Lanka graduate to an upper middle-income country in the near futute. So, there is a fear that Sri Lankan exports will lose concessional access to certain markets, as middle income countries are not provided with the same (Central Bank of Sri Lanka 2014).

On a positive note, newly built port in Hambantota and the expanded Colombo port further increase the global connectivity of the country. Further, Sri Lanka has recorded positive growth in exports of services. In addition, average manufacturing wages in Sri Lanka have not risen much and remain competitive compared with those of Bangladesh and China - Sri Lanka's two main competitors in the area of garments, its principal export item (Bell 2014). Reforms have been done to remove barriers, if any, in order to improve business environment and the results are evident. In the global competitiveness index Sri Lanka was placed $65^{\text {th }}$ in 2013-14 compared to $68^{\text {th }}$ in 2012-13 and was well ahead of other regional countries (World Economic Forum 2015). Sri Lanka was placed $85^{\text {th }}$ place in the Doing Business Report 2014 compared to $81^{\text {st }}$ in 2013 and was named the regional leader in implementing regulatory reforms (World Bank 2014). However, just leading these indexes at regional levels would not be sufficient and competitiveness should be enhanced continuously to face challenges in today's highly competitive environment.

In this backdrop, it is an opportune time to analyse the export efficiency of Sri Lanka and the potential it could have achieved in exports if not for the barriers both within and outside its territory. For this, I intend to use the gravity model with stochastic frontier approach for the period from 2000 to 2013 using the panel data for 56 major export destinations. However, there are hardly any previous published studies which have used this method to analyze export potential of Sri Lanka.

Following are the objectives of this study.

1. To access what the potential of Sri Lanka's exports during the period 2000-2013 would have been and compare it with the actual export performance

2. To identify what had been the determinants of Sri Lanka's exports during the above period

3. To identify what has constrained Sri Lanka from achieving its export potential

\section{Literature Review}

The gravity model, originating from Newtonian physic notion, is an ex-post analysis approach which uses historical data to guide policy by explaining its effect where it has already been implement. Famous physics theory of gravity developed by Newton argues that the gravitational force between two masses is related to the distance between them. Similarly, the gravity model of trade postulates that the size of bilateral trade flows between two countries is related to the economic distance represented by physical distance (D) and the sizes of the two economies proxied by their Gross Domestic Products (GDP), $Y_{i}$ and $Y_{j}$.

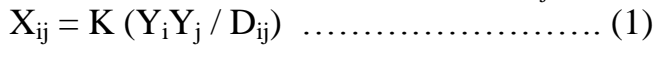

Initially, gravity model of trade drew a lot of criticism for being poor in economic theoretical underpinning. However, Anderson (1979) initiated the work to provide validity for gravity model in his study where he derived relationship using expenditure systems where goods were differentiated from the country of origin (Armington preferences) and transport costs were proxied using physical distance. Next noteworthy contribution came from Bergstrand (1985) as he derived gravity model as a partial equilibrium subsystem of general gravity equilibrium. Earlier model specifications came with the assumption of frictionless trade between the countries or 'iceberg transport costs' and trade between countries are proportionate to the product of their income level. Trade intensity analysis used the relative size of an economy as a proxy for what its potential trade was. However, the assumptions of frictionless trade or iceberg transport costs make this model weak in recognizing trade frictions (Armstrong 2007).

Some of the issues encountered in estimating gravity models and the solutions developed to address those have enriched the literature and enhanced the theoretical underpinning. Anderson and Wincoop (2003) argues that relative trade costs need to be controlled for a better specification of gravity model and that excluding proxy for multilateral resistance might result in biased and inconsistent coefficients in an OLS estimation due to omitted variable effect. 
Endogeneity issues are quite frequent in policy impact studies in trade due to the fact that direction of causal effect might take either way. GMM techniques might fail if correct lags are not selected and use of instrumental variables might suffer from not selecting a suitable instrument (Koh 2013).

Stochastic frontier model (SFM) was introduced in 1977 by two groups independently, namely, Aigner et al (1977) and Meeusen and Broeck (1977). They argued that due to firm level inefficiencies, the actual production falls short of the potential output. In this model, it is assumed that the error term comprises two components, a positive term which captures the random disturbances and measurement errors, and a non-negative term which captures the inefficiencies in the production.

As highlighted by Baldwin and Taglioni (2006) there are three errors which are encountered frequently in applied work. Gold medal error is the omission of the multilateral resistance terms; silver medal error refers to incorrect averaging of bilateral trade, that is, taking the log of average trade flows instead of the average of the logs; bronze medal error occurs if an inappropriate price index used which would wrongly deflate trade values. Endogeneity, the zeros problem and heteroscedasticity are the other issues that are frequently encountered. Khalirajan (2008) argues that standard gravity model captures only the physical distance between countries as a constraint and not the social and institutional constraints for trade in the countries. When SFM is applied to international trade, it is assumed that all restrictions on trade, such as institutional constraints, are captured in the inefficiency term (Armstrong 2007).

The main difference in the conventional gravity model and the gravity model with SFM approach in trade is their treatment of estimating the potential trade. Earlier estimations of the gravity model involved deriving potential trade by using Ordinary Least Square (OLS) regression analysis (Deluna 2013). However, OLS estimates represent the centre values of the data whereas trade potential implies the maximum possible trade. So, SFM provides an estimation procedure that identifies the upper limit of the data and not the average level of them to find the upper limit of the production. Trade potential is the frontier derived from estimation in a hypothetical case where frictionless and free trade is in existence all over the world and with best achievable trade technologies (Kalirajan 1999).

Further, Khalirajan and Singh (2008) highlights three broad factors which constrain trade flows; 'natural factors' such as distance, population size, transport and transaction costs, 'behind the border factors' such as red tape, infrastructural and institutional rigidities in the exporting country, as well as 'beyond the border factors' which are of two forms namely, explicit beyond the border factors and implicit beyond the border factors. Explicit factors are the observable factors such as tariffs and implicit factors are the constraints in institutional structures and infrastructure which are difficult to measure.

The stochastic frontier gravity model, which combines the gravity model and the stochastic frontier approach, takes on the following form.

Xijt $=\mathrm{f}($ Zijt,$\beta) \exp ($ vijt - uijt $) \ldots \ldots \ldots \ldots \ldots \ldots(2)$

Where,

$X_{i j t}$ are trade flows from country $i$ to country $j$ at time $t, f\left(Z_{i j t}, \beta\right)$ is a function of a vector of trade determinants and a vector of parameters to be estimated $\mathrm{V}_{\mathrm{ijt}}$ is the random error term which captures all other disturbances including 'implicit beyond the border'. $\mathrm{V}_{\mathrm{ijt}}$ is an independently and identically distributed (iid) error term with a normal distribution of mean zero and variance $\sigma_{\mathrm{v}}{ }^{2} \mathrm{U}_{\mathrm{ijt}}$ is non-negative error term which represents 'behind the border' inefficiencies in the exporting country that prevents it from reaching its trade frontier; $\mathrm{U}_{\mathrm{ijt}}$ is a non-negative iid term with a truncated half-normal distribution with mean $\mu$ and variance $\sigma_{\mathrm{u}}^{2}$.

\section{Data and Methodology}

The 56 countries in the sample were chosen on the basis of higher value of the goods exported to them from Sri Lanka as well as on the availability of data. Data on bilateral exports of Sri Lanka was obtained from the Direction of Trade Statistics (DOTS) of the International Monetary Fund (2015). Data on geographical distance and colonial relationship was obtained from the Centre d'Etudes Prospectives et d'Informations Internationales (CEPII). GDP data in current USD of Sri Lanka and partner countries was obtained from the World Development Indicators (WDI) of the World Bank. There is no widely used index to represent the trade resistance in importing countries. Accordingly, the reciprocal value of the trade freedom index, published by the Heritage Foundation was used as a proxy for beyond the border constraints. Higher the trade resistance higher will be the beyond the border constraints (Deluna 2013). This index gives a score of zero for no trade freedom and hundred for full trade freedom. Accordingly, the trade resistance index value will be higher for a country with low trade freedom, and vice versa. Data on bilateral and regional trade agreements, preferential access to markets were obtained from the website of the Department of Commerce, Sri Lanka. GDP is used as a proxy for the income level of the economies and distance as a measure of geographical or physical barriers to trade. 
Population represents the market size of the economy, that is, higher the population, bigger will be the market for exports and there will be more opportunities for trade with diverse demand. But, at the same time, countries with smaller populations tend to trade more as smaller domestic market does not provide sufficient opportunities for trade.

Another explanation for population variable to be negative is that economies with larger populations having an absorption effect (Martinez-Zarzoso and Nowak-Lehmann 2003).So, the expected sign for population would be either negative or positive. Mean tariff rate of all products of the import country was used as the exports of Sri Lanka comprises both finished goods as well as primary and Agricultural goods. If the tariff rates of the importers' country are reduced there will be more trade. Therefore, a negative coefficient is expected for tariff variable.

There was no source of readily available data on bilateral real exchange rate (REER) for all the countries in the study. Accordingly, REER was calculated using the official exchange rate and consumer price index (CPI) available in the World Development Indicators (WDI). Since the official exchange rate in WDI is expressed as domestic currency per US dollar, bilateral nominal exchange rate (NEER) is calculated by dividing the domestic country's official exchange rate by the partner country's official exchange rate. Then REER was calculated by multiplying the NEER with the ratio of the CPI of Sri Lanka to the CPI of importing country (Koh 2013). Therefore, a fall in the real exchange rate represents currency appreciation for the domestic country. Depreciation of the Sri Lankan Rupee is expected to increase exports. Therefore, the coefficient of the real exchange rate is expected to be negative for exports.

Absolute value of the difference between the per capita GDP of the Sri Lanka and the import country provides a proxy for difference in income levels and factor endowments (Koh 2013). There are two concepts with regard to the difference in income levels, namely, Linder hypothesis and Hecksher-Ohlin theory. Linder (1961) argues that there will be more opportunities for trade if the income levels of the two countries are the same. However, according to Hecksher-Ohlin theory, higher the difference in income levels and factor endowments, there will be more trade. Therefore, we expect a negative sign if Linder hypothesis holds and a positive sign if the Hecksher-Ohlin theory holds.

We use dummy variable COL, which considers whether the importer country has a colonial relationship with Sri Lanka, on the assumption that those with same colonial relationships have similar systems and institutions in place, hence less impediments. Further, a long tradition of commercial ties would lead to increased trade. So, the expected relationship is positive.

In addition, it is expected that regional and bilateral trade agreements as well as the arrangements that provide preferential access to exports of Sri Lanka have a positive impact on exports, which is captured by dummy variables on trade agreements, PTA and SAFTA. Dummy variable PTA captures preferential access to countries in European Union as well as other developed countries such as USA and Japan. SAFTA came into force in 2006 and represents access to Sri Lankan exports to South Asian economies, namely India, Pakistan and Bangladesh, being the three major economies included in this study. Other common variables that we find in augmented gravity models, such as common border and language are not applicable as Sri Lanka is an island and speaks a unique language. Exports of Sri Lanka with its 56 important export destinations in terms of value exported from year 2000 to 2013 are modelled as:

$\log ($ Xijt $)=\beta_{0}+\beta_{1} \log ($ GDPit $)+\beta_{2} \log ($ GDPjt $)+\beta_{3} \log ($ POPit $)+\beta_{4} \log ($ POPjt $)+\beta_{5} \log ($ PCGDPDijt $)+\beta_{6} \log ($ DISTij $)+$ $\beta_{7} \log (1+$ TARIFFjit $)+\beta_{8} \log \left(\right.$ REER $\left._{\mathrm{jt}}\right)+\beta_{9} \log \left(\mathrm{TR}_{\mathrm{jt}}\right)+\beta_{10}$ COLij $+\beta_{11}$ PTAijt $+\beta_{12}$ SAFTAijt where;

$\mathrm{Xijt}=$ Value of exports from Sri Lanka to country $\mathrm{j}$ in year $\mathrm{t}$, GDPit $($ GDPjt $)=$ Sri Lanka's GDP (country j's GDP) in year t, POPit $(\mathrm{POPjt})=$ Sri Lanka's population (country j's population) in year $\mathrm{t}$, PCGDPDijt $=$ absolute value of per capita differential of Sri Lanka and country $j$ in year $t$, DISTij $=$ distance between Sri Lanka and country $j$,

TARIFFjt $=$ country $j$ 's mean tariff rate in year $t$, REER $_{\mathrm{ijt}}=$ Bilateral Real Exchange Rate between Sri Lanka and country $\mathrm{j}$, TRjt $=$ Trade resistance index value of country $\mathrm{j}$ in year $\mathrm{t}$, $\mathrm{COL}_{\mathrm{ij}}=$ colonial link or relationship of Sri Lanka with country $\mathrm{j}$ (dummy variable), $\mathrm{PTA}_{\mathrm{ijt}}=$ Preferential trade agreement of Sri Lanka with country $\mathrm{j}$ in year $\mathrm{t}$ (dummy variable) $\mathrm{SAFTA}_{\mathrm{ijt}}=$ Free trade agreement of Sri Lanka with SAFTA member $\mathrm{j}$ in year $\mathrm{t}$ (dummy variable)

\section{Results and Discussion}

All the statistical tests were done using STATA version 12. Prior to the estimation, all the time series variables were tested for unit root. There are several tests available for unit root tests in panel data. Levin-Lin-Chu test for panel data requires that there are few panels and more time periods, as the ratio of the number of panels to time periods need to be zero asymptotically. 
So, Harris-Tzavalis test was used for this study, which assumes that number of time periods is fixed while the number of panels tends to infinity, that is higher number of panels compared to time periods are required. However, the results show that $\mathrm{GDP}_{\mathrm{i}}, \mathrm{POP}_{\mathrm{i}}, \mathrm{GDP}_{\mathrm{j}}$ and $\mathrm{POP}_{\mathrm{j}}$ are non-stationary. It is common in empirical analysis that population and GDP variables to have unit roots. Nevertheless, another test called Hadri test was also employed.

Unlike other tests, in this test null hypothesis is that all panels are stationary and the alternative hypothesis is that at least one panel has a unit root. According to it, all the variables with time series nature were found to be stationary and results were highly significant too. For the purposes of this paper, it is considered that one test result is enough to conclude that data are stationary or not. Accordingly, it is concluded that all variables are stationary.

Estimation is done using the stochastic frontier approach (SFA) (Table 1). Results of pooled OLS are also presented, but only as a reference, as OLS estimates are biased and inconsistent due to heterogeneity across countries. SFA was employed with time-varying decay inefficiency model. This is justified by the eta value of the output which is statistically significant. The Gamma value $(\gamma)$ of 0.797 justifies the use of a stochastic frontier model to estimate export potential as it implies that both behind the border constraints and the country-specific beyond the border factors of importing countries are responsible for a major portion of the total variation in the model.

Table 1: Estimation Results for Exports

\begin{tabular}{|c|c|c|}
\hline & OLS & SFA \\
\hline $\log (G D P)$ & $\begin{array}{r}-0.323 \\
(0.331)\end{array}$ & $\begin{array}{c}-0.284 \\
(0.194)\end{array}$ \\
\hline $\log \left(G D P_{i}\right)$ & $1.19988 \%$ & $0.93388 \%$ \\
\hline & $(0.0446)$ & $(0.075)$ \\
\hline $\log$ (DIST) & $\begin{array}{r}-0.783 * 8 \% \\
(0.0889)\end{array}$ & $\begin{array}{r}-0.734^{* 8} \\
(0.279)\end{array}$ \\
\hline $\log (\mathrm{PQP})$ & $\begin{array}{r}3.382 \\
(5.177)\end{array}$ & $\begin{array}{r}1.317 \\
(2.361)\end{array}$ \\
\hline $\log (P Q P)$ & $\begin{array}{r}-0.171^{* 8 \%} \\
(0.0428)\end{array}$ & $\begin{array}{r}0.002 \\
(0.094)\end{array}$ \\
\hline $\log (T R)$ & $\begin{array}{r}0.00987 \\
(0.0486)\end{array}$ & $\begin{array}{r}-0.0876^{88} \\
(0.0311)\end{array}$ \\
\hline $\log (\mathrm{DPCGDP})$ & $\begin{array}{r}0.00866 \\
(0.0517)\end{array}$ & $\begin{array}{r}0.0683^{* 8} \\
(0.0304)\end{array}$ \\
\hline $\log$ (Tariff) & $\begin{array}{r}-0.0445 \\
(0.0513)\end{array}$ & $\begin{array}{r}-0.0699 \\
(0.046)\end{array}$ \\
\hline Log(REER) & $\begin{array}{r}-0.038 \\
(0.0294)\end{array}$ & $\begin{array}{r}-0.0097 \\
(0.0303)\end{array}$ \\
\hline $\mathrm{COL}$ & $\begin{array}{r}0.668^{* 8 * 8} \\
(0.106)\end{array}$ & $\begin{array}{l}0.531^{8} \\
(0.319)\end{array}$ \\
\hline PTA & $\begin{array}{r}-0.303 * 8 \\
(0.107)\end{array}$ & $\begin{array}{r}-0.0501 \\
(0.0608)\end{array}$ \\
\hline $\begin{array}{l}\text { SAFTA } \\
\text { constant }\end{array}$ & $\begin{array}{r}0.498 \times 8 \\
(0.255) \\
-53.73 \\
(79.31)\end{array}$ & $\begin{array}{r}0.179 \\
(0.143) \\
-13.79 \\
(36.191)\end{array}$ \\
\hline $\begin{array}{l}\text { No. of Observations } \\
\mathrm{R}^{2} \\
\text { Adiusted } \mathrm{R}^{2}\end{array}$ & $\begin{array}{r}784 \\
0.7249 \\
0.7206\end{array}$ & 784 \\
\hline $\begin{array}{l}\text { Adjusted } \mathrm{N} \\
\text { eta }\end{array}$ & & $\begin{array}{c}0.00857^{88} \\
(0.00415)\end{array}$ \\
\hline Gamma & & $\begin{array}{r}0.797 \\
(0.0359)\end{array}$ \\
\hline
\end{tabular}

Source: Authors estimates

Note: ***,** and * represent significance levels at 1,5 and 10 per cent respectively. Figures in parenthesis are the standard errors of the coefficients.

All SFA coefficients show the expected sign. Foreign GDP variable show a positive sign as expected and is statistically significant. Accordingly, when the GDP of partner countries grow the exports of Sri Lanka to them increase due to higher income and demand. However, GDP of Sri Lanka shows a negative sign though it is statistically not significant. This is partly due to the fact that ratio between exports to GDP of Sri Lanka has been falling continuously and alarmingly since 2000 (Kalegama 2015). In addition, other sectors in the economy have been growing faster than the export sector. Both population parameters are positive though statistically not significant. 
Distance is negatively correlated with the exports of Sri Lanka with statistical significance, which implies that even today, with modern transport facilities distance still matters. This also implies that higher transport as well as transaction costs involved in exporting to countries farther away may be an impediment.

DPCGDP is positive and significant. So, the Hekscher-Ohlin theory holds for the exports of Sri Lanka. The differences in income level and factor endowments with respect to partner countries have a positive effect on exports of Sri Lanka. The coefficient for tariff rates has a negative sign and is not statistically significant. So, higher tariff rates in importing countries do not have significant impact on the exports of Sri Lanka.

This may be due to two reasons. Garment of Sri Lanka, being the main export, have enjoyed preferential access when GSP was in force and they enjoy a niche market in EU and USA where demand may be price inelastic.

REER comes with the expected negative sign, so the depreciation of Sri Lankan rupee has helped in maintaining the competitiveness of Sri Lanka's exports. However, the coefficient is not statistically significant. Further, TR is negative and is statistically significant. So, the beyond the border factors such as the institutional and infrastructure constraints in importing countries significantly hamper the exports of Sri Lanka.

Table 2: Results of Sri Lanka's potential exports: 2000-2013 average (USD Mn)

\begin{tabular}{|c|c|c|c|c|c|c|c|}
\hline Country & $\begin{array}{l}\text { Actual } \\
\text { Exports }\end{array}$ & $\begin{array}{l}\text { Potential } \\
\text { Exports }\end{array}$ & $\begin{array}{c}\text { Ratio of } \\
\text { actual to } \\
\text { potential } \\
\%\end{array}$ & Country & $\begin{array}{l}\text { Actual } \\
\text { Exports }\end{array}$ & $\begin{array}{l}\text { Potential } \\
\text { Exports }\end{array}$ & $\begin{array}{c}\text { Ratio of } \\
\text { actual to } \\
\text { potential } \\
\%\end{array}$ \\
\hline Australia & 82.79 & 739.71 & 11.19 & Mauritius & 2.15 & 29.11 & 7.39 \\
\hline Austria & 14.94 & 363.07 & 4.11 & Mexico & 58.79 & 469.86 & 12.51 \\
\hline Bahrain & 5.44 & 59.01 & 9.22 & Morocco & 1.95 & 55.18 & 3.53 \\
\hline Bangladesh & 27.00 & 326.29 & 8.27 & Netherland & 135.21 & 678.43 & 19.93 \\
\hline Belgium & 330.71 & 398.86 & 82.91 & New Zealand & 13.20 & 95.49 & 13.82 \\
\hline Brazil & 18.22 & 654.14 & 2.79 & Nigeria & 2.66 & 228.41 & 1.16 \\
\hline Bulgaria & 2.17 & 46.72 & 4.64 & Norway & 12.55 & 387.36 & 3.24 \\
\hline Canada & 89.14 & 866.14 & 10.29 & Oman & 5.83 & 91.34 & 6.38 \\
\hline China & 46.57 & 215.71 & 21.59 & Pakistan & 53.29 & 390.50 & 13.65 \\
\hline Colombia & 5.20 & 35.09 & 14.82 & Peru & 6.00 & 57.19 & 10.49 \\
\hline Denmark & 18.29 & 55.53 & 32.94 & Philippines & 6.73 & 188.57 & 3.57 \\
\hline Finland & 16.63 & $2,018.57$ & 0.82 & Poland & 26.81 & 383.00 & 7.00 \\
\hline France & 141.43 & $2,920.00$ & 4.84 & Portugal & 5.32 & 178.93 & 2.97 \\
\hline Germany & 338.57 & 343.64 & 98.52 & Qatar & 4.67 & 250.72 & 1.86 \\
\hline Hong Kong & 81.71 & $2,207.71$ & 3.70 & Romania & 2.97 & 151.03 & 1.97 \\
\hline Hungary & 2.93 & 128.09 & 2.29 & Russia & 190.71 & 920.21 & 20.72 \\
\hline India & 382.86 & $3,250.71$ & 11.78 & Saudi Arabia & 40.16 & 564.21 & 7.12 \\
\hline Indonesia & 39.30 & 775.93 & 5.06 & Singapore & 132.29 & $1,003.14$ & 13.19 \\
\hline Iran & 107.64 & 338.14 & 31.83 & Slovenia & 1.12 & 45.92 & 2.44 \\
\hline Ireland & 22.36 & 195.93 & 11.41 & South Africa & 17.21 & 240.57 & 7.15 \\
\hline Israel & 53.14 & 431.79 & 12.31 & Spain & 47.50 & $1,005.00$ & 4.73 \\
\hline Italy & 307.29 & $1,724.90$ & 17.81 & Sweden & 40.79 & 436.86 & 9.34 \\
\hline Japan & 175.71 & $4,352.14$ & 4.04 & Switzerland & 54.36 & 524.86 & 10.36 \\
\hline Jordan & 36.00 & 41.46 & 86.83 & Thailand & 49.36 & 476.36 & 10.36 \\
\hline Kenya & 4.94 & 56.29 & 8.78 & Turkey & 94.57 & 623.57 & 15.17 \\
\hline Kuwait & 23.43 & 264.07 & 8.87 & UK & 877.14 & $2,022.14$ & 43.38 \\
\hline Madagascar & 1.39 & 10.43 & 13.33 & USA & $1,964.29$ & $7,116.43$ & 27.60 \\
\hline Malaysia & 35.38 & 713.36 & 4.96 & Vietnam & 13.81 & 126.74 & 10.90 \\
\hline
\end{tabular}

Source: Authors estimates

Coefficient for COL has a positive sign and is statistically significant. This implies that Sri Lanka's export performance is helped by the colonial relationships, especially with the commonwealth of the former British Empire. This also could be due to the Fact that most of the commonwealth countries share similar systems and institutions in place, such the multiparty parliamentary system. 
SAFTA dummy has a positive sign while dummy for PTA has a negative sign. Nevertheless, both dummies are statistically not significant. However, SAFTA has been useful in promoting Sri Lanka's exports in the south Asian region. Negative sign for PTA, would be due to the continued improvement of exports to European Union even though GSP+ benefits of Sri Lanka to the European Union was scrapped. It is emphasized that most of the countries under the variable PTA are European.

Table 3: Region-wise Export Results: 2000-2013 average (USD Mn)

\begin{tabular}{|c|c|c|c|c|}
\hline Region & Actual & Exports & Potential Exports & $\begin{array}{c}\text { Ratio of Actual to Potential } \\
\%\end{array}$ \\
\hline North America & & $2,112.22$ & $8,452.43$ & 24.99 \\
\hline Europe & & $2,684.37$ & $15,552.62$ & 17.26 \\
\hline Oceania & & 95.99 & 835.20 & 11.49 \\
\hline Latin America & & 29.42 & 746.42 & 3.94 \\
\hline Africa & & 32.25 & 675.17 & 4.78 \\
\hline South Asia & & 463.15 & $3,967.50$ & 11.67 \\
\hline Middle East & & 280.98 & $2,291.46$ & 12.26 \\
\hline Rest of Asia* & & 580.86 & $10,059.66$ & 5.77 \\
\hline
\end{tabular}

Source: Authors estimates

*South East Asia with China and Japan

Accordingly, overall estimation results are in line with the expected results even though some variables were found to be statistically not significant. Further, Maximum Likelihood Estimates of gravity stochastic frontier model was used to estimate the destination-wise potential of the exports of Sri Lanka. Country-wise and region-wise results are presented in the Table 2 and Table 3, respectively. Overall, estimates of potential shows that Sri Lanka has tapped only approximately 15 per cent of its export potential during the period from year 2000 to 2013, which is alarmingly low by any standard. Countries to which Sri Lanka has exported close to its potential are Germany, Belgium and Jordan for which actual to potential export ratios are $98.52,82.91$ and 86.83 per cent, respectively. However, Jordan is not a major export destination of Sri Lanka. Out of the major trading partners, actual to potential export ratio for USA, UK and India stands at 27.60, 43.38 and 11.78 per cent, respectively.

In a region-wise analysis, it appears that North America had been the preferred destination for Sri Lanka's exports followed by EU, Middle East and the South Asia. Despite being a member of SAFTA, its low volume of exports to the neighbouring south Asian region is discouraging. Further, Sri Lanka's exports to South East Asia too are terribly low despite it being the region which grows fastest in the world.

So, the results clearly show that Sri Lanka falls behind its potential in all export destinations though at different levels. This is where the policy would play a role in turning fortunes in export sector. Lack of diversification of the composition of the exports of Sri Lanka is also a concern at a time world traded goods profile is going through significant changes. Current export basket is concentrated to few low value added exports (Kalegama 2015). Garments account for 44 per cent of the exports while Agricultural exports account for 25 per cent which comprises mainly of tea (14 per cent), rubber and coconut (CBSL 2014). Value addition in garments is low and the agricultural goods are exported as primary goods with minimum value addition. Of the new industries, some prospects are there for leather products and food and beverage products. Inability to penetrate into high-tech exports would be a major concern, especially when peers such as Vietnam are doing far better in that aspect (Kalegama 2015). Not only products, major export destinations are also concentrated into few countries, mainly in the EU and the USA. This is mainly due to the fact that export basket comprises mainly of garment products. So, in the case of Sri Lanka, lack of product diversification has lead to lack of market diversification as well. Further, in terms of the actual to potential ratios, a larger gap could be observed in exports to Asian countries except for India and China. Our results clearly show that Sri Lanka has not tapped its potential in the Asian region which grows faster than any other region in the world and has become the powerhouse of world trade.

Results also show that being part of trade agreements, especially SAFTA, had been fruitful for Sri Lankan exports with a positive coefficient, though with no statistical significance. However, whether Sri Lanka uses the regional and bilateral trade agreements to its fullest potential is the problem. Sri Lanka's exports to India, under the India-Sri Lanka Free Trade Agreement (ISFTA) improved to the level of US dollars 376 million in 2014 by only US dollars 9mn increase compared to that in 2013. Further, exports under the ISFTA comprised only 60 per cent of total exports to India from Sri Lanka in 2014. 
Since ISFTA, Sri Lanka's exports to India has grown by 6 folds even though the utilization rate has been falling from a peak of 100 per cent in 2003 (Kalegama 2015).Under the Pakistan-Sri Lanka Free Trade Agreement (PSFTA), Sri Lanka exported goods worth US dollars 52 million to Pakistan in 2014 which was only about 70 per cent of Sri Lanka's total exports to Pakistan. Under the agreement on South Asian Free Trade Area (SAFTA), Sri Lanka exported goods worth only US dollars 13 million in 2014 to Bangladesh, India, Maldives, Nepal and Pakistan in comparison to US dollars 2 million in 2013 (CBSL 2014). Exports to Southeast Asia and China are also an area that needs attention as there is huge untapped potential.

In this regard, steps taken to enter into a free trade agreement with China, BIMSTEC arrangements and discussions going on with Vietnam for a bilateral agreement is encouraging. This provides evidence that Sri Lanka should be able to be competitive to promote its exports in the region.

Another aspect Sri Lanka could focus on for mitigating gap between actual and potential exports is expanding its integration to international trade through global value chains (GVC). Under GVC, a single country does not specialize in a particular product, but rather in one process of a long chain of value addition. Vietnam and Malaysia had been successful in this at some stage of their recent history. As per UNCTAD estimates close to 60 per cent of global trade consists of trade in intermediate goods and services (UNCTAD 2014). However, the 'behind the border' barriers should be reduced in order to be competitive in the world stage.

\section{Conclusions}

This research employs an augmented gravity model to estimate the export potential of Sri Lanka for the period 20002013 and to identify the determinants of exports. Importing country's GDP and colonial relationship have positive impact on Sri Lanka's exports. In addition, the difference between the factor endowments has a positive and significant impact which is in accordance with the Hekscher-Ohlin theory. The distance and trade resistance of the importing country have negative and significant impact on Sri Lanka's exports. Tariffs of the importing country also have a negative impact which, however, is not significant. Sri Lanka's actual exports have achieved only 15 per cent of its potential during the period 2000 to 2013 which is disappointing considering priorities given to the exports sector by the stakeholders. Further, depreciation of Sri Lana rupee has not helped significantly for Sri Lankan exports to grow.

There is considerable differences in region-wise performance which shows that Sri Lanka has done considerably well in the traditional markets such as the US and EU but has fallen well short of its potential in the other regions. However, concentration into few markets and few products would be of high risk, especially when possibility of another financial crisis in developed world is never ruled out. Further, there is research space for further study to assess whether global financial crisis had an impact on Sri Lanka's exports.

Results also imply that country specific behind the border constraints act as major impediment to export growth. This is visible in Sri Lanka's ranking in doing Business and Global competitiveness indexes where no considerable gain was seen for last few years. However, data limitations restrict the study from employing an elaborative inefficiency model which would have identified the specific factors which impede or enhance efficiency. Accordingly, it is difficult to make policy recommendations on how to improve efficiency.

However, results show that there is huge untapped potential for Sri Lankan exports, especially in Asia. So, diversification of export destinations and commodity portfolio would be a priority for policy makers.

\section{References}

Aigner, D., Knox Lovell, C.A. \& Schmidt, P. (1977), Formulation and Estimation of Stochastic Frontier Production Function Models, Journal of Econometrics, vol. 6, no. 1, pp. 21-37.

Anderson, J.E. (1979), A Theoretical Foundation for the Gravity Equation, American Economic Review, vol. 69, no. 1, pp. 106-116.

Anderson, J.E. \& van Wincoop, E. (2003), Gravity with Gravitas: A Solution to the Border Puzzle, American Economic Review, vol. 93, no. 1, pp. 170-192.

Annual Report (2014), Central Bank of Sri Lanka, Colombo, Sri Lanka. Viewed on 20.05.15.

Armstrong, S. (2007), 'Measuring Trade and Trade Potential: A Survey', Asia Pacific Economic Papers, no. 368.

Asian Development Outlook (2015), Asian Development Bank, Mannila, Phillipines. [online] Available: http://www.adb.org/sites/default/files/publication/154508/ado-2015.pdf (May 31,2015).

Baldwin, R. \& Taglioni, D. (2006), Gravity for Dummies and Dummies for Gravity Equations, NBER Working Paper, no. 12516, National Bureau of Economic Research, Cambridge MA.

Bell, O. (2014), Sri Lanka's new beginning, Investment Week,,61, [online] Available: http://search.proquest.com/docview/1623095376?accountid=8330 (May 10, 2015) 
Bergstrand, J.H. (1985), The Gravity Equation in International Trade: Some Microeconomic Foundations and Empirical Evidence, Review of Economics and Statistics, vol. 67, no. 3, pp. 474-481.

Direction of Trade Statistics (2015), International Monetary Fund, Washington DC, USA.

Deluna Jr, R. (2013), Trade performance and potential of the Philippines: An application of stochastic frontier gravity model, Munich Personal RePEc Archive, MPRA Paper No. 51677 [online] Available: http://mpra.ub.unimuenchen.de/51677/ (May 10, 2015)

Kalegama, S. (2015), Towards the 2020 Vision of US\$20bn Exports and Beyond - Pressing Concerns and Emerging Opportunities, Presentation to the National Chamber of Commerce of Sri Lanka on 15.01.15 [online] Available: http://www.ips.lk/images/News/2015/29_01_2015_annual_general_meeting/NCE\%20ppp1.pdf (May 15, 2015)

Kalirajan, K. \& Singh, K. (2008), A Comparative Analysis of China's and India's Recent Export Performances, Asian Economic Papers, vol. 7, no. 1, pp. 1-28.

Kalirajan, K. \& Shand, R.T. (1999), Frontier Production Functions and Technical Efficiency Measures, Journal of Economic Surveys, vol.13, no.2.

Koh, W. (2013) ,Brunei Darussalam's Trade Potential and ASEAN Economic Integration: A Gravity Model Approach, Southeast Asian Journal of Economics, vol. 1, no. 01, pp 67-89.

Linder, S.B. (1961), An Essay on Trade and Transformation, John Wiley, New York.

Meeusen, W. and van den Broeck, J. (1977), Efficiency estimation from Cobb-Douglas production functions with composed error, International Economic Review, vol. 18, no. 2, pp. 435-444.

Martinez-Zarzoso, I. \& Nowak-Lehman, F. (2003), Augmented gravity model: An empirical application to MercosurEuropean Trade flows, Journal of Applied Economics, vol.5, no. 002, pp.291-316.

The Global Competitiveness Report 2013-2014, World Economic Forum. [online] Available: http://www3.weforum.org/docs/WEF_GlobalCompetitivenessReport_2013-14.pdf (May 10, 2015)

World Investment Report 2014, United Nations Conference on Trade and Development 2014, UNCTAD, viewed 20 March 2015.

World Development Indicators, The World Bank, Washington DC, USA. 